\title{
Regeneration patterns of the late-successional Abies alba Mill.: inhibition in monospecific stands and colonization in mixed stands
}

\author{
Jarosław G. Paluch $^{1}$ - Zbigniew Kołodziej ${ }^{1}$. Jerzy Skrzyszewski ${ }^{1}$ - Leszek Bartkowicz ${ }^{1}$. \\ Piotr Gruba ${ }^{1}$
}

Received: 11 March 2016 / Accepted: 4 July 2016 / Published online: 20 July 2016

(C) INRA and Springer-Verlag France 2016

\begin{abstract}
- Key message In Abies alba Mill. stands and mixed stands of A. alba and Picea abies L. (H. Karst), microsites neighbouring the trunks of adult trees were more conducive to $A$. alba regeneration. Although at the stand level, the effect of Fagus sylvatica L. was positive; the local effect of the adult $F$. sylvatica neighbourhood was insignificant. Hence, forming mixed stands with a fine-grained mosaic of admixed species might better facilitate natural regeneration of $A$. alba than monospecific stands.

- Context The establishment of natural regeneration in Abies alba Mill. stands is a slow, spatially heterogeneous and stochastic process. Recent studies based on inventory data
\end{abstract}

\section{Handling Editor: Aaron R Weiskittel}

Contribution of the co-authors JGP designed the experiment, coordinated the research project and completed the data analysis; ZK and JS supervised the field measurements; LB supervised the canopy analyses; PG supervised the soil analyses; all co-authors contributed to the writing.

Jarosław G. Paluch

j.paluch@ur.krakow.pl

Zbigniew Kołodziej

rlkolodz@cyf-kr.edu.pl

Jerzy Skrzyszewski

rlskrzy@cyf-kr.edu.pl

Leszek Bartkowicz

1.bartkowicz@ur.krakow.pl

Piotr Gruba

rlgruba@cyf-kr.edu.pl

Faculty of Forestry, Agricultural University, Al. 29 Listopada 46, 31-425 Krakow, PL, Poland indicate that $A$. alba more readily regenerates in mixed stands than in monospecific stands.

- Aims The objective was to examine how this positive association evidenced at the stand level operates on the scale of microsites with contrasting local species composition and stand density.

- Methods In 8 monospecific and 22 mixed stands with Fagus sylvatica L. or Picea abies L. (H. Karst), microsites with a contrasting density of $A$. alba seedlings were selected and compared in terms of local species composition, stand density, canopy characteristics and topsoil properties.

- Results In A. alba stands, seedling density was positively associated with the proximity of adult trees. In mixed stands of A. alba and $P$. abies, adult trees of both species exerted a positive effect on $A$. alba regeneration, but the $P$. abies neighbourhood influenced regeneration occurrence more strongly than the A. abies neighbourhood. In mixtures with $F$. sylvatica, however, the effect of local stand density and local species composition was not evidenced at all.

- Conclusion Although at the stand level, P. abies and F. sylvatica exert a positive effect on $A$. alba regeneration, on the microsite scale, their influences differ. In stands with a dominance of $A$. alba, the hampered seedling establishment in gaps may be considered an inhibitive effect that facilitates the emergence of other species.

Keywords Mixed stand $\cdot$ Microsite $\cdot$ Spatial pattern $\cdot$ Species coexistence $\cdot$ Facilitation

\section{Introduction}

In temperate zones, although late-successional tree species frequently show similar life strategies and compete for similar resources in relatively homogeneous environments, they form 
mixed stands in a wide range of sites (Roženbergar et al. 2007; Szwagrzyk et al. 2012). Species coexistence under such conditions contravenes the logic that species with the highest long-term relative population growth rate in admixture with other species should oust all others (Wilson 2011). It is therefore reasonable to assume that the temporal persistence of mixed stands involves mechanisms that stabilize complex species composition and counteract exclusion of certain of its components through density-dependent processes.

Although shifts in species abundance may appear at different development stages (Mori and Komiyama 2008; Rousset and Lepart 2000), one crucial prerequisite for mixture persistence is successful reproduction. In particular, mixed species composition may be stabilized at this stage by negative feedback versus conspecific regeneration and/or positive effects versus the regeneration of heterospecific species (Busing 1996; Catovsky and Bazzaz 2002). These associations potentially may involve a range of factors, including seed dispersal (Snyder and Chesson 2004), light regime (Roženbergar et al. 2007), density-dependent and host-specific pests (granivory, herbivory, pathogens) (Baraza et al. 2006; Nopp-Mayr et al. 2012), topsoil properties (Bigelow and Canham 2015) or allelopathic effects (Becker and Drapier 1985). The spatial scale at which these factors operate may differ strongly and range from an area encompassing the entire stand to close proximity of single trees. In fact, research shows that in mixed forests, microsites occupied by different species may differ from the neighbouring background in many properties important for establishing regeneration, including light conditions (Stadt and Lieffers 2000), topsoil moisture and $\mathrm{pH}$ (Paluch and Gruba 2012), ectohumus layer thickness (Bens et al. 2006; Buck and St Clair 2014), forest floor vegetation (Saetre 1999), abundance of soil fungi (Frankland 1998) and fungal pathogens (Kotanen 2007) and mycorrhiza colonization rates (Cline et al. 2007) or seedling mycorrhiza diversity (Grebenc et al. 2009).

Several examples have been documented of certain tree species regenerating more easily in mixtures with another species than in monospecific stands (Arbour and Bergeron 2011; Yamazaki et al. 2009). In most cases, however, this situation is exemplified by tree species of different successional status with few well-documented examples of interactions between species coexisting at the same stage of a succession sequence. One example is forests with late-successional Abies alba Mill. In pure stands, natural regeneration of $A$. alba accumulates slowly because gaps (including small inter-crown openings) and close-to-trunk locations can be unfavourable for seedlings: the former are associated with increased fungal pathogen attacks and the latter with water deficiency that hinder seedling growth (Paluch and Stepniewska 2012). In effect, in monospecific stands, the spatial pattern of regeneration is very irregular, and A. alba seedlings are mostly absent in canopy openings, the microsites with the lowest competitive pressure from surrounding adult trees and hence the highest chances of successful recruitment. On the other hand, several studies have indicated that $A$. alba regenerates more readily in mixed stands with late-successional Fagus sylvatica L. and/or Picea abies L. (H. Karst) than in monospecific stands (e.g. Šimak 1951; Jaworski 1973; Hofmeister et al. 2008; Paluch and Jastrzębski 2013), although little is still known about mechanisms, spatial scale and intensity of this positive effect.

The aim of this present study, therefore, is to test whether the regeneration facilitation effect evidenced in mixed stands at the stand level also operates on the level of intra-stand variation in microsites with different local species composition and stand density. The specific hypotheses are as follows: (i) microsites with different regeneration density will differ in local species composition and local stand density attributes, (ii) microsites with a higher regeneration density will show a higher proportion of $F$. sylvatica and $P$. abies trees in the upper canopy, (iii) the positive effect of admixtures will diminish with a decreasing proportion of $A$. alba trees and reduced availability of their seeds and (iv) the spatial effect of $P$. abies and F. sylvatica will differ because of differences in these species' properties, including tree architecture, litter properties and spatial pattern of litter dispersal.

\section{Material and methods}

\subsection{Study site}

The study was conducted in the Western Carpathians (southeastern Poland) in stands located in the lower montane belt of the altitudinal zone $500-950 \mathrm{~m}$ a.s.l., between $18.794^{\circ} \mathrm{E}$ and $22.722^{\circ} \mathrm{E}$ longitude and $49.133^{\circ} \mathrm{N}$ and $49.784^{\circ} \mathrm{N}$ latitude. In this region, A. alba commonly grows on eutric, loamy cambisols developed on flysch sediments. Depending on altitude, location and aspect, the growth period (with a mean daily temperature above $5^{\circ} \mathrm{C}$ ) is ca $180-200$ days, the average annual temperature is $5-7^{\circ} \mathrm{C}$ and the annual precipitation is $750-1450 \mathrm{~mm}, 60 \%$ occurring between May and October. The mean annual temperature increases by about $0.5^{\circ} \mathrm{C}$ per each $100 \mathrm{~m}$ increase in altitude (Paszyński and Niedzwiedź 1999).

For this study, 8 pure A. alba stands (hereafter, Abies stands) were selected together with 11 mixed stands of $A$. alba and F. sylvatica (hereafter, Fagus-Abies stands) and 11 mixed stands of A. alba and P. abies (hereafter, Picea-Abies stands). Each species composition variant was represented by two to four stands in the eastern, middle or western part of the Western Carpathian massif. In addition to species composition, the criteria for stand selection were homogeneity of site conditions, the occurrence of a naturally established A. alba seedling bank of largely young individuals (i.e. not older than 25 years with a mean height between 0.1 and $0.3 \mathrm{~m}$ ), low 
competition from forest floor plants (less competitive, low herbal plants and arborescent species forming a loose and discontinuous cover) and a low intensity of silvicultural operations during recent decades (only thinning operations without cuttings aimed directly at promoting regeneration). The stands were between 80 and 130 years in age and originated from natural regeneration in the shelterwood system. According to field measurements, the stand basal area ranged between 29 and $54 \mathrm{~m}^{2} \mathrm{ha}^{-1}$ (mean $=42.2 \mathrm{~m}^{2} \mathrm{ha}^{-1}$ ) in the Abies and Picea-Abies stands and between 31 and $44 \mathrm{~m}^{2} \mathrm{ha}^{-1}$ $\left(\right.$ mean $=36.9 \mathrm{~m}^{2} \mathrm{ha}^{-1}$ ) in the Fagus-Abies stands. In the Abies stands, the contribution of A. alba trees to the stand basal area was above $90 \%$ (mean $=94 \%)$; in the FagusAbies stands, it ranged between 16 and $61 \%$ (mean $=34 \%$ ); and in the Picea-Abies stands, it fell between 34 and $85 \%$ $($ mean $=73 \%)$.

\subsection{Data collection}

In the 30 stands selected, based on stand shape and size, between two and five transects $5 \mathrm{~m}$ wide and $1500 \mathrm{~m}$ in total length were traced out. These transects were divided into 50$\mathrm{m}$-long sectors, and in each segment, a patch about $10 \mathrm{~m}^{2}$ in area with a locally maximal density of $A$. alba regeneration was identified (hereafter, favourable microsite). The minimal distance between the neighbouring favourable microsites was limited to $25 \mathrm{~m}$. Between each pair of favourable microsites selected, a patch with a locally minimal density of $A$. alba regeneration was identified (hereafter, unfavourable microsite). This sampling procedure resulted in the identification of 30 favourable microsites and 30 unfavourable microsites in each of the stands.

In the centre of every selected patch, a circular sample plot $1 \mathrm{~m}^{2}$ in area was placed and all A. alba seedlings were counted. The term "seedlings" as used here refers to all individuals under $50 \mathrm{~cm}$ in height (but usually between 0.1 and $0.3 \mathrm{~m}$ ) except for the current year's germinants. Trees growing within a $10 \mathrm{~m}$ radius (horizontal distance) of the plot centres were mapped using a compass and an ultrasonic distance meter. The $10-\mathrm{m}$ radius was assessed as sufficient to capture local variation in stand density and species composition. Measurements were then taken of all live trees with a diameter at breast height (dbh) $\geq 7 \mathrm{~cm}$ and all the stumps of trees removed approximately during the last two decades with a diameter at $0.3 \mathrm{~m} \geq 20 \mathrm{~cm}$. The measurement records included species, the dbh of live trees and the diameters of the removed trees.

To characterize canopy openness (i.e. the fraction of open sky unobstructed by vegetation in a specified canopy region) and light conditions in the favourable and unfavourable microsites, in June-August 2014, 60 hemispherical images were taken of each stand in the selected sample plots. All these photos were obtained in overcast conditions from $0.6 \mathrm{~m}$ above the ground using a Nikon E4500 camera with a Nikon FC-E8 fisheye converter affixed to a tripod and a universal O-mount with a northfinder (Régent Instruments Inc., Canada).

In each stand, in both favourable and unfavourable microsites, topsoil samples were taken using a soil sampler tool (50 $\mathrm{mm}$ in diameter) up to a depth of $20 \mathrm{~cm}$ (inclusive of the organic layer). The samples from plots with the same regeneration status (i.e. 30 samples from favourable microsites or 30 samples from unfavourable microsites) were pooled, packed in plastic bags, tied up, marked and transported to a refrigerator in which they were kept at $-3{ }^{\circ} \mathrm{C}$ until laboratory analysis began. In total, the Abies $(N=8)$, Picea-Abies $(N=11)$ and Fagus-Abies stands $(N=11)$ were represented by16, 22 and 22 soil samples, respectively, collected from both favourable and unfavourable microsites.

\subsection{Soil analysis}

Before the soil could be sieved, the living roots and rock particles were removed and the soil samples air-dried for about 1 week at room temperature. The samples were then sieved using a $2-\mathrm{mm}$ sieve. The fractions of clay $(<0.002 \mathrm{~mm})$, silt $(0.05$ to $0.002 \mathrm{~mm})$ and sand particles $(0.05$ to $2 \mathrm{~mm})$ were determined using laser diffraction (Analysette 22, Fritsch GmbH, Germany). Soil pH was measured electrochemically with a combination electrode in a suspension with distilled water and $1 \mathrm{~mol} \mathrm{dm}{ }^{-3} \mathrm{KCl}$ solution (1:5 mass-to-volume ratio) after $24 \mathrm{~h}$ of equilibration (Buurman et al. 1996). Exchangeable calcium $\left(\mathrm{Ca}^{2+}\right)$, potassium $\left(\mathrm{K}^{+}\right)$, magnesium $\left(\mathrm{Mg}^{2+}\right)$ and sodium $\left(\mathrm{Na}^{+}\right)$were extracted with $1 \mathrm{~mol} \mathrm{~L}^{-1} \mathrm{CH}_{3} \mathrm{COONH}_{4}$ at $\mathrm{pH}=7$. The soil samples were then mixed with an extractant $(10 \mathrm{~g}$ in $30 \mathrm{~mL})$ and equilibrated. After $24 \mathrm{~h}$, the suspensions were filtered $(0.45 \mu \mathrm{m}$ millipore membrane), the soil was washed with additional extractant and the total volume was made up to $100 \mathrm{~mL}$ (Jackson 1958). Lastly, the concentration of cations was determined by means of ICP (ICP-OES Thermo iCAP 6500 DUO, Thermo Fisher Scientific Inc., USA). The total carbon (C) and total nitrogen $(\mathrm{N})$ contents of the soil were determined in fine subsamples ground in a ball mill using an LECO CNS TrueMac Analyzer (Leco Co., USA).

\subsection{Data analysis}

The canopy pictures were analysed using the WinSCANOPY Pro 2006a programme (Régent Instruments Inc., Canada) with manufacturer-suggested camera and lens specifications. In most cases, the automatic pixel classification method based on grey levels yielded acceptable results because of the good picture quality. Sporadically, the threshold values were adjusted manually (usually between 235 and 250 on a $0-255$ scale). For every sample plot, the analysis determined gap fractions in the canopy regions given by the zenith angles $0-10^{\circ}, 0-20^{\circ}$ 
and $0-30^{\circ}$; the total light factor and direct light factor (the ratios of the average daily direct and diffuse radiation and the average daily direct radiation, respectively, received under and over the canopy during the growing season) and the indirect light factor (the ratio of indirect radiation received under and over the canopy assuming a standard overcast sky model).

The set of variables adopted as potential indicators of favourable versus unfavourable microsites were as follows: the gap fractions in the canopy regions as defined above; the direct, indirect and total light factors; the basal areas of live or removed trees and the proportion of admixed species (i.e. F. sylvatica in Fagus-Abies stands or P. abies in Picea-Abies stands) in local basal areas within a $2,3, \ldots, 10 \mathrm{~m}$ radius from the sample plots; and soil characteristics (fraction of sand, silt and clay particles, $\mathrm{pH}$, total $\mathrm{N}$, total $\mathrm{C}, \mathrm{C}: \mathrm{N}$ ratio, the sum of base cations: $\left.\mathrm{Ca}^{2+}, \mathrm{K}^{+}, \mathrm{Mg}^{2+}, \mathrm{Na}^{+}\right)$.

Preliminary computations included routine analyses of the variable distributions, spatial autocorrelations (Moran's I tests) and associations between predictors and response variables (scatterplot analyses and Pearson correlations). These were followed by a comparison of the mean values of the variables in the favourable versus the unfavourable microsites. Skewed distribution problems were eliminated by the application of bootstrap procedures testing the equality of means (10,000 bootstrap samples, Efron and Tibshirani 1993, pp. 220-224). For multiple comparisons in the distance gradients, Bonferroni corrections were used. Differences between the topsoil characteristics were tested via one-sample bootstrap procedure (10,000 bootstrap samples, Efron and Tibshirani 1993, pp. 224-227) that serves as a simulation-based alternative for Wilcoxon signed-rank tests and sign tests. Data analysis was carried out using Statistica (Stat Soft Inc., USA), version 9.1.

\section{Results}

\subsection{Variation in regeneration density}

In the Abies stands, the average seedling density per $\mathrm{m}^{2}$ was 22.4 in the favourable microsites and 1.8 in the unfavourable microsites. In the Picea-Abies stands, seedling density in both types of microsites was lower than in the Abies stands (18.5 and 0.9 per $\mathrm{m}^{2}$, respectively). The lowest regeneration densities were registered in the Fagus-Abies stands in which the average number of seedlings per $\mathrm{m}^{2}$ was 11.0 in the favourable microsites and 0.7 in the unfavourable microsites. The regeneration densities in favourable and unfavourable microsites in the stands studied are illustrated in Fig. 1. Overall, the analysis reveals no significant relations between stand-level seedling density and either stand basal area $(r=-0.16, \mathrm{n}$. s.) or light conditions as determined by the total light factor $(r=0.18, \mathrm{n} . \mathrm{s}$. $)$.

\subsection{Effect of local stand density}

In the Abies stands, the favourable microsites were characterized by a significantly higher local basal area than the unfavourable microsites (Fig. 2a). These differences were highest at the smallest spatial scale analysed (i.e. within a $2 \mathrm{~m}$ radius), decreased with the increasing radius of the surroundings and maintained statistical significance up to a radius of $4 \mathrm{~m}$. The differences in local basal area (within a $2 \mathrm{~m}$ radius) between the favourable and unfavourable microsites amounted to $69 \mathrm{~cm}^{2} \mathrm{~m}^{-2}$ on average (about $70 \%$ of the standard deviation unit in terms of stand-level variation) and ranged between 29 and $194 \mathrm{~cm}^{2} \mathrm{~m}^{-2}$ in individual stands. Similar differences between the favourable and unfavourable microsites were observable in the Picea-Abies stands (on average $40 \mathrm{~cm}^{2} \mathrm{~m}^{-2}$ ) (Fig. 2c). In the individual stands, the differences ranged between 15 and $82 \mathrm{~cm}^{2} \mathrm{~m}^{-2}$ and attained negative values in two stands with the highest stand basal area. In contrast to the conifer stands, no differences related to local basal area manifested between the favourable and unfavourable microsites in the Fagus-Abies stands (Fig. 2b), in which the differences ranged between 18 and $35 \mathrm{~cm}^{2} \mathrm{~m}^{-2}$ and amounted to $10 \mathrm{~cm}^{2} \mathrm{~m}^{-2}$ on average. Nor were any such differences observable for removed trees in the surroundings of favourable versus unfavourable microsites.

In the Abies and Picea-Abies stands, the favourable microsites differed from the unfavourable microsites in a lower gap fraction in canopy regions defined by the zenith angles $10^{\circ}(p<0.001)$ and $20^{\circ}(p<0.001)$ (Fig. 3a, c). These differences diminished and ceased to be statistically significant, however, as the zenith angle and canopy region increased. Although this tendency was also discernible in the Fagus-Abies stands (Fig. 3b), the differences were smaller and statistically significant only for the zenith angle of $10^{\circ}$ $(p<0.001)$. The total radiation received by favourable and unfavourable microsites differed only insignificantly by 0.4 $1.1 \%$.

\subsection{Effect of local species composition}

The analysis of the Fagus-Abies series revealed no differences between the two types of microsites in the basal area of F. sylvatica trees (Fig. 4a). In the Picea-Abies stands, however, the favourable microsites were characterized by a significantly higher proportion of P. abies in the local basal area than found for the unfavourable microsites (Fig. 4b). The highest differences occurred on the smallest spatial scale analysed, within a $2 \mathrm{~m}$ radius. In the single stands, these differences ranged between 11 and $33 \%$ and amounted to $15 \%$, on average. The significantly higher proportion of $P$. abies in the favourable microsites was statistically assured up to a distance of $3 \mathrm{~m}$ and discernible in the entire spatial range analysed. 
Fig. 1 Regeneration density in favourable and unfavourable microsites (median values, 10 th and 90th percentiles): a Abies stands, b Fagus-Abies stands, c Picea-Abies stands. The stands are arranged by ascending basal area
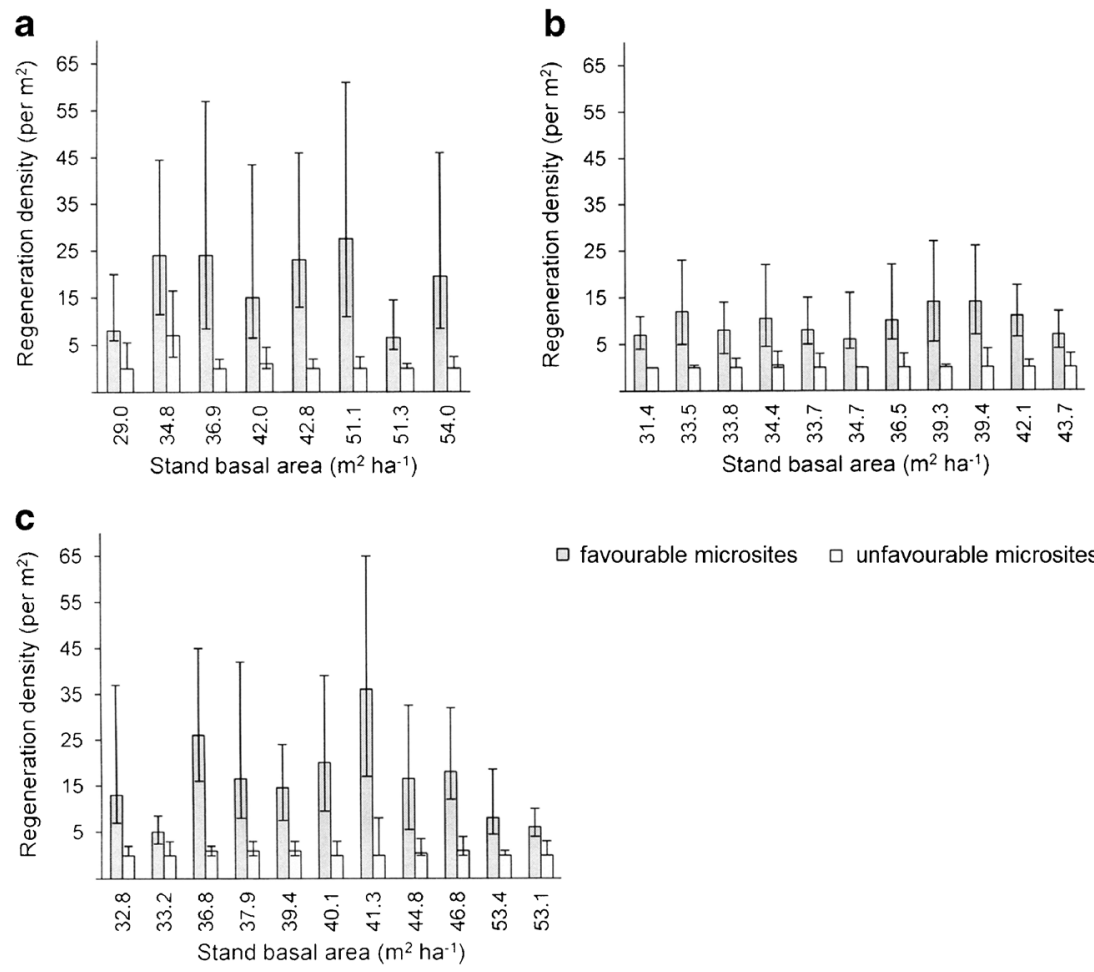

\subsection{Topsoil characteristics}

Except for a higher proportion of clay fraction (9.9 versus $6.6 \%, p=0.02)$ and a lower $\mathrm{C}: \mathrm{N}$ ratio $(14.7$ versus 16.6 , $p=0.02$ ) in the Abies stands relative to the Fagus-Abies stands, the majority of the topsoil characteristics analysed showed no significant differences between the stand composition series. In the Abies and Picea-Abies stands, however, the favourable microsites showed a higher $\mathrm{C}$ content and $\mathrm{C}: \mathrm{N}$ ratio than the unfavourable microsites, together with a lower topsoil $\mathrm{pH}, \mathrm{Ca}^{2+}$ concentration and sum of base cations (Table 1). These tendencies were not discernible in the FagusAbies stands. Nonetheless, some Fagus-Abies stands did have considerable $\mathrm{C}$ content (between 5.3 and $8.9 \%$ ) together with
Fig. 2 Mean values and bootstrapped $95 \%$ confidence intervals for local basal area of live trees in radii between 2 and $10 \mathrm{~m}$ from the favourable and unfavourable microsites: a Abies stands, b Fagus-Abies stands, c Picea-Abies stands. The significantly different pairs of values (two-sided bootstrap tests with the Bonferroni correction for multiple comparisons, $\alpha=0.05 / 9$ ) are designated by enlarged marks a

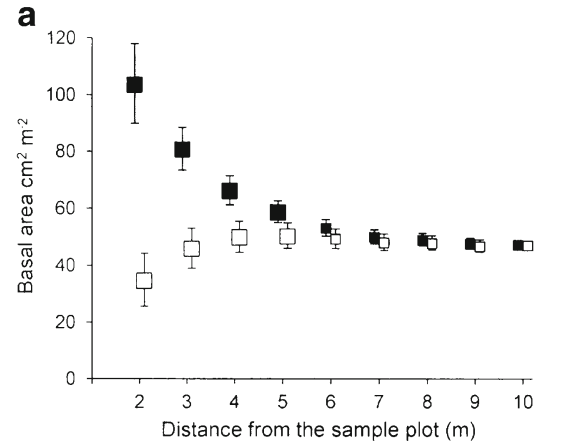

C

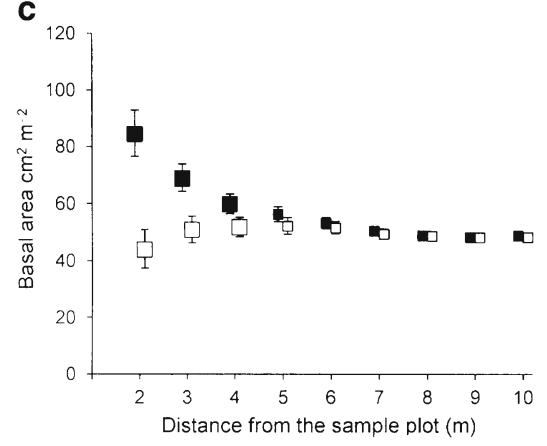

b

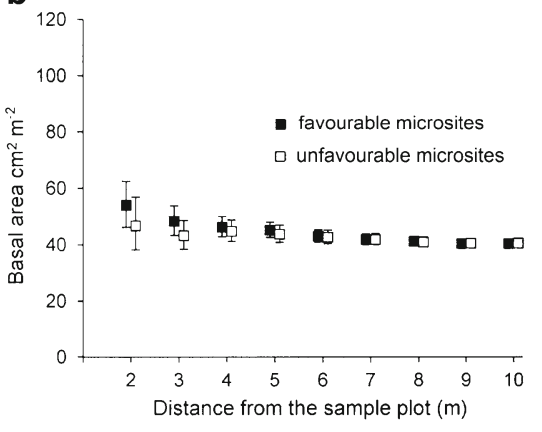


Fig. 3 Mean values and bootstrapped $95 \%$ confidence intervals for canopy gap fractions in favourable and unfavourable microsites for different zenith angles: a Abies stands, b FagusAbies stands, $\mathbf{c}$ Picea-Abies stands
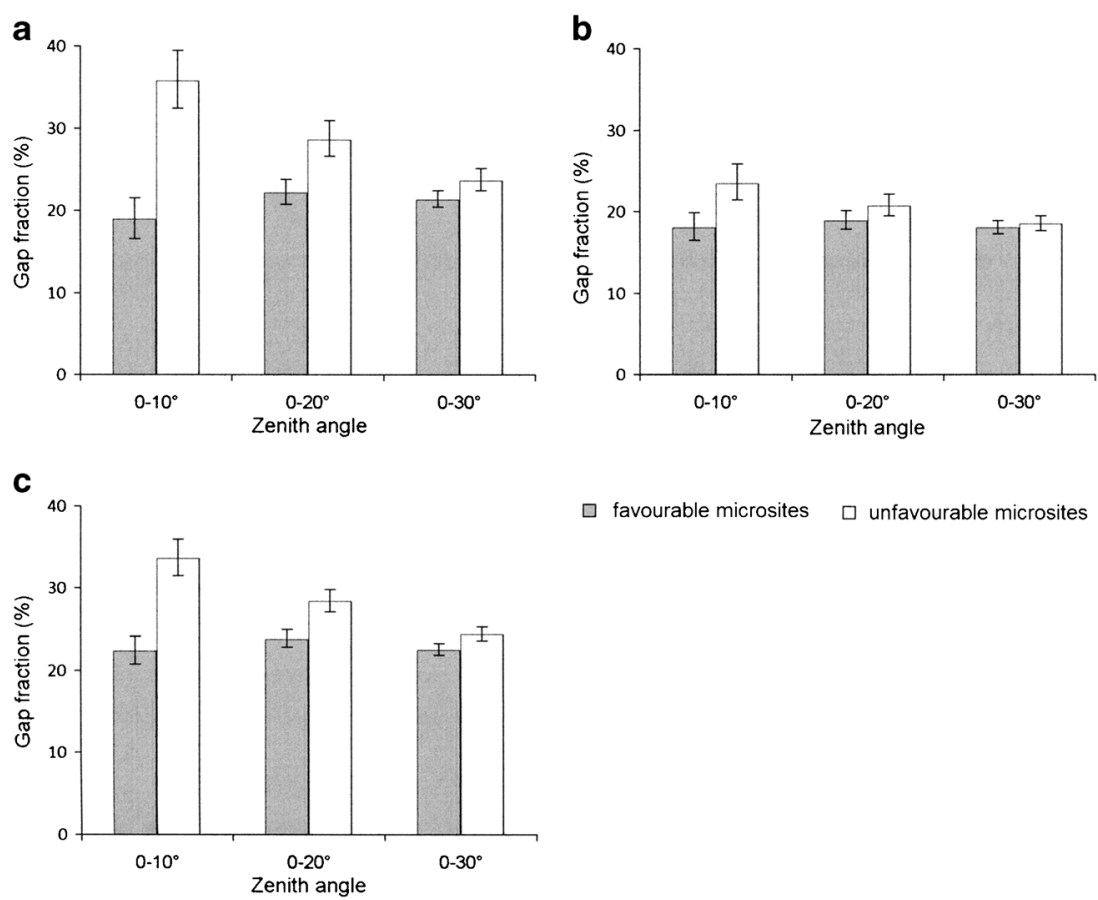

$\square$ favourable microsites $\square$ unfavourable microsites low topsoil pH values (below 4.0). In these stands, however, in contrast to the conifer stands, the higher $\mathrm{C}$ levels and lower $\mathrm{pH}$ occurred in the unfavourable microsites. In general, in the Fagus-Abies stands, the microsites contrasting in regeneration density differed significantly only in $\mathrm{Ca}^{2+}$ concentration and the sum of base cations (Table 1).

\section{Discussion}

\subsection{Availability of seeds versus availability of favourable microsites}

The associations analysed here should be considered from the perspectives of two different factor categories: the availability of seeds and the availability of favourable microsites in which seeds can survive and germinate, and germinants can establish

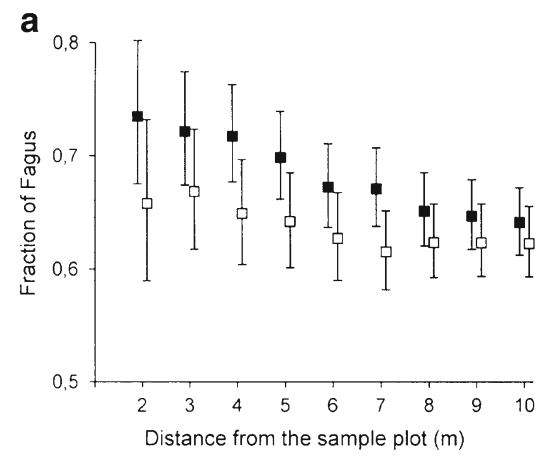

Fig. 4 Proportion of admixed species in local basal area in different radii from favourable and unfavourable microsites (mean values and bootstrapped $95 \%$ confidence intervals): a Fagus-Abies stands, b seedling banks (Nuttle and Haefner 2005; Snyder and Chesson 2004). Dependent on stand density, the median dispersal distance in forest interiors of the winged and relatively heavy seeds produced by $A$. alba (on average, 50-55 g per 1000 dried seeds, Schütt 1991; Suszka 1983) has been estimated at between 6.0 and $21.5 \mathrm{~m}$, and the maximum density of fallen seeds per area unit has been observed at a distance between 3.0 and $6.0 \mathrm{~m}$ from the mother tree (De Andrés et al. 2014; Marczyk 2012; Sagnard et al. 2007). Paluch (2011) also identified a significant spatial and temporal correlation of ground seed density in A. alba stands that could be linked to the arrangement of seed-bearing trees, variation in these trees' seed output and local stand density. Hence, a higher ground seed density could be expected in patches with a higher basal area of adult $A$. alba exemplars.

The mixed stands studied here, however, yielded no evidence of close association between seed rain intensity and

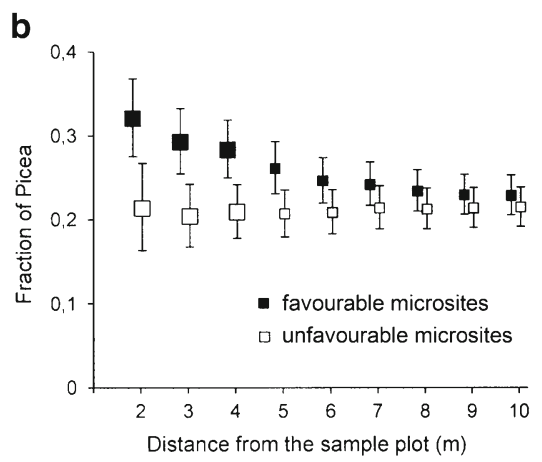

Picea-Abies stands. The significantly different pairs of values (twosided bootstrap tests with Bonferroni correction for multiple comparisons, $\alpha / 9=0.05$ ) are designated by enlarged squares 
Table 1 Topsoil characteristics (means and standard errors) in the microsites favourable (+) and unfavourable (-) for A. alba regeneration

\begin{tabular}{|c|c|c|c|c|c|c|c|c|c|c|}
\hline \multirow[t]{2}{*}{ Characteristics } & & \multicolumn{3}{|c|}{ Abies $(N=8$ stands $)$} & \multicolumn{3}{|c|}{ Fagus-Abies $(N=11$ stands $)$} & \multicolumn{3}{|c|}{ Picea-Abies ( $N=11$ stands $)$} \\
\hline & & $(+)$ & $(-)$ & & $(+)$ & $(-)$ & & $(+)$ & $(-)$ & \\
\hline Sand & $(\%)$ & $24.9(2.9)$ & $20.6(2.9)$ & & $33.1(4.3)$ & $31.3(4.6)$ & & $29.5(3.6)$ & $25.2(4.7)$ & \\
\hline Silt & $(\%)$ & $66.9(2.7)$ & $67.0(3.3)$ & & $60.1(3.8)$ & $62.2(4.0)$ & & $63.3(3.3)$ & $66.8(4.4)$ & \\
\hline Clay & $(\%)$ & $8.1(0.7)$ & $11.7(2.6)$ & & $6.8(0.6)$ & $5.2(0.7)$ & & $7.2(0.5)$ & $7.9(0.5)$ & \\
\hline $\mathrm{pH}\left(\mathrm{H}_{2} \mathrm{O}\right)$ & N/A & $4.1(0.09)$ & $4.4(0.13)$ & $* *$ & $4.3(0.11)$ & $4.3(0.15)$ & & $4.1(0.07)$ & $4.4(0.09)$ & $* * *$ \\
\hline Total N & $(\%)$ & $0.22(0.012)$ & $0.21(0.011)$ & & $0.23(0.03)$ & $0.26(0.04)$ & & $0.22(0.02)$ & $0.21(0.02)$ & \\
\hline Total C & $(\%)$ & $3.6(0.3)$ & $2.9(0.3)$ & $* *$ & $3.8(0.5)$ & $4.5(0.8)$ & & $3.9(0.3)$ & $3.1(0.2)$ & $* * *$ \\
\hline $\mathrm{C}: \mathrm{N}$ ratio & N/A & $15.4(0.7)$ & $14.0(0.6)$ & $* *$ & $16.4(0.8)$ & $16.8(0.9)$ & & $16.3(0.6)$ & $15.2(0.5)$ & $* * *$ \\
\hline Sum of base cations & $\mathrm{cmol} \mathrm{kg}^{-1}$ & $1.4(0.3)$ & $2.6(0.8)$ & $*$ & $1.4(0.2)$ & $2.3(0.4)$ & $*$ & $1.6(0.3)$ & $2.9(0.9)$ & $*$ \\
\hline
\end{tabular}

The significantly different pairs of values (one-sample bootstrap test) are designated by $*(\alpha<0.01), * *(\alpha<0.05)$ or $* * *(\alpha<0.01)$, respectively

microsite preferences of $A$. alba regeneration. In the FagusAbies stands with a relatively low density of adult $A$. alba trees (mean basal area of A. alba $=12.3 \mathrm{~m}^{2} \mathrm{ha}^{-1}$ ), no positive effect of seed-bearing trees was observable, and in the PiceaAbies stands, the positive effect of $P$. abies in local species composition held approximately constant irrespective of the proportion of A. alba in the stand species composition, which ranged between 34 and $85 \%$. This finding suggests that the more favourable conditions for regeneration establishment created by F. sylvatica and P. abies were capable of counterbalancing the lower availability of seeds. The relevance of such microsite filtering for A. alba regeneration was also emphasized by de Andrés et al. (2014), who found spatially uncoupled patterns of seed and seedling density in both a Pyrenean monospecific and a mixed Fagus-Abies stand.

\subsection{Effect of local stand density}

In line with several research conclusions that microsites under too open canopies are not conducive to A. alba regeneration (Diaci 2002; Grassi and Bagnaresi 2001; Paluch 2005a; Roženbergar et al. 2007), the results obtained in the Abies and Picea-Abies stands point to a positive association between regeneration occurrence and local stand density as expressed by local basal area. The temporal permanence of such a pattern of regeneration establishment was also validated for uneven-aged stands of $A$. alba in the Western Carpathians, in which advance regeneration was positively correlated with adult trees and trees of the lower stand layer (Paluch 2005b).

This positive association, however, may not be directly linked to seedbed characteristics because topsoil features that matter for regeneration establishment, like ectohumus layer depth or seedbed moisture, tend to deteriorate with decreasing distance from the tree trunks of conifer species (e.g. Liski 1995; Paluch and Gruba 2011; Penne et al. 2010). In fact, this effect was also observable in the present research, which found a higher organic $\mathrm{C}$ content and $\mathrm{C}: \mathrm{N}$ ratio together with a lower $\mathrm{pH}$ and base cation concentration in the microsites characterized by higher local stand density. Other explanations such as seed burying, seed predation or vegetation competition (Hunziker and Brang 2005) stemming from the lower attractiveness of $A$. alba seeds for rodents (Schreiner et al. 2000) also seem less probable, as does the moderate vegetation cover in the stands under study (i.e. $<50 \%$ maximal coverage by a loose and discontinuous layer of less competitive, low herbal plants). It is also worth mentioning that no notable differences were observable in the germination and juvenile survival of a control group of seedlings sown on mingled topsoil samples taken from the favourable and unfavourable habitats in Abies, Picea-Abies and FagusAbies stands and then artificially sheltered in a nursery and subjected to contrasting watering regimes (unpublished data).

One explanation proposed for the positive association between abundant regeneration occurrence and local stand density is a mechanism involving spatial diversification of fungal infections in below-crown zones and inter-crown openings (Paluch and Stepniewska 2012). This explanation assumes that germinants growing in gap environments are more frequently moistened, exposed to contact with soil particles spread onto their cotyledons by rain drops splashing on the ground and thus more subject to infections by aeroaquatic and aquatic fungi (e.g. Gyoerffyella rotula, Pseudaegerita sp., Varicosporium elodeae, Jankowiak et al., submitted to Fungal Ecology). The ectohumus layer, which is thicker in the neighbourhood of stems and frequently absent under canopy openings on eutric sites in the Western Carpathians (Paluch and Gruba 2011), may additionally separate plants and diminish their contact with mineral soil, thereby reducing the seedling mortality caused by fungal pathogen attacks.

Canopy openings with moderately developed ground vegetation are usually regarded as hot-spots characterized by reduced competition from the over-story stand and a higher availability of resources, which offer better chances of successful recruitment to the canopy layer than do the below- 
crown zones (e.g. Woods 1984; Nagel et al. 2010). Hence, in stands with a dominance of $A$. alba, the hampered seedling establishment in gaps may be treated as an inhibitive effect that facilitates the emergence of other species, which are given more chances of successful advancement.

\subsection{Species effect}

The species examined here differed in their influence on A. alba regeneration dependent on spatial scale. The effect of A. alba and P. abies was maximal in the shortest distance analysed (i.e. $2 \mathrm{~m}$ ), decreased as the distance from stems increased and corresponded approximately to the horizontal crown projections. The similarity of the spatial pattern of regeneration establishment in the proximity of adult $A$. alba and $P$. abies trees suggests the same mechanism of spatial diversification of fungal infections in below-crown zones and intercrown openings (Paluch and Stępniewska 2012). It remains unexplained, however, why below-crown zones in the proximity of $P$. abies were more preventive of pathogen attacks than those in the proximity of A. alba. Both species have a similar rate of precipitation interception (between 20 and $80 \%$, depending on stand characteristics and rain intensity) (Otto 1994), meaning that the zones sheltered by their crowns should potentially have experienced no difference in wetting frequency. One possible working hypothesis is that the ectohumus layer, which tends to be roughly double the thickness in the neighbourhood of $P$. abies trunks as compared to A. alba trunks (Paluch and Gruba 2012), may have modified pathogen behaviour and/or infection mechanisms and hindered the spreading of fungal spores onto the above-ground parts of juvenile seedlings.

In comparison to A. alba and P. abies, the effect of $F$. sylvatica was more spatially diffused. $F$. sylvatica is a broad-leaved species characterized by a more efficient stem flow, a higher $\mathrm{pH}$ and a lower $\mathrm{C}: \mathrm{N}$ ratio of litter-fall and atmospheric deposition interception than $A$. alba and P. abies (Augusto et al. 2002). As a result, on eutric cambisols, the neighbourhoods of this species have a weaker effect on the decrease of topsoil moisture and $\mathrm{pH}$ than A. alba and P. abies (Paluch and Gruba 2012). Yet in spite of these contrasting characteristics, at the stand level, $F$. sylvatica exerts a similarly positive effect on A. alba regeneration as P. abies (Paluch and Jastrzębski 2013). Although the findings of this present study suggest that this positive stand-level effect does not operate at the local scale, the mechanism underlying $F$. sylvatica's positive influence may be similar to that in other species; that is, the influence may be linked to the ectohumus layer's preventive effect against fungal infections. Given the wider litter-fall shadows of broad-leaved species and the more homogenous distribution of their litter on the ground (Jonard et al. 2006; Staelens et al. 2003), in mixed stands with $F$. sylvatica, the stand-level effect may be more pronounced than the local effects attributable to the proximity of tree stems. At the same time, changes in stand species composition may also be accompanied by shifts in the frequency of occurrence and the virulence of pathogens.

\section{Conclusions}

The above analysis has clearly demonstrated that microsites with differing regeneration density also differ significantly in local species composition and that favourable microsites are characterized by a higher proportion of $P$. abies. Although at the stand level, the effect of $F$. sylvatica ranked between that of $P$. abies and $A$. alba, the local effect of the $F$. sylvatica neighbourhood was insignificant. Hence, although forming mixed stands of A. alba with $P$. abies and $F$. sylvatica may ameliorate conditions decisive for establishing A. alba regeneration, the limited spatial scale of tree influence identified in this study implies that significant improvement might be achieved using homogenous distribution and considerable partitioning of the admixed species. One viable candidate could be a fine-grained mixture of $P$. abies and A. alba, although in the case of the highly competitive $F$. sylvatica, mixtures with small clumpings or two-layered stands with a subordinate beech layer would be preferable.

Acknowledgments The authors wish to thank three referees for valuable and pertinent comments.

\section{Compliance with ethical standards}

Funding This work was supported by the National Science Centre, Poland [2012/07/B/NZ9/00953 to J.P.].

\section{References}

Arbour ML, Bergeron Y (2011) Effect of increased Populus cover on Abies regeneration in the Picea-feathermoss boreal forest. J Veg Sci 22:1132-1142. doi:10.1111/j.1654-1103.2011.01314.x

Augusto L, Ranger J, Binkley D, Rothe A (2002) Impact of several common tree species of European temperate forests on soil fertility. Ann For Sci 59:233-253. doi:10.1051/forest:2002020

Baraza E, Zamora RA, Hódar J (2006) Conditional outcomes in plantherbivore interactions: neighbours matter. Oikos 113:148-156. doi:10.1111/j.0030-1299.2006.14265.x

Becker M, Drapier J (1985) Rôle de l'allélopathie dans les difficultés de régénération du sapin (Abies alba Mill.). Propriétés phytotoxiques des hydrosolubles d'aiguilles de sapin. Oecol Plantarum 5:347-356

Bens O, Buczko U, Sieber S, Hüttl RF (2006) Spatial variability of O layer thickness and humus forms under different pine beech-forest transformation stages in NE Germany. J Plant Nutr Soil Sci 169:515. doi:10.1002/jpln.200521734 
Bigelow SW, Canham CD (2015) Litterfall as a niche construction process in a northern hardwood forest. Ecosphere 6:1-14. doi:10.1890/ES14-00442.1

Buck JR, St Clair SB (2014) Stand composition, proximity to overstory trees and gradients of soil moisture influence patterns of subalpine fir seedling emergence and survival. Plant Soil 381:61-70. doi:10.1007/s11104-014-2094-9

Busing RT (1996) Estimation of tree replacement patterns in an Appalachian Picea-Abies forest. J Veg Sci 7:685-694. doi: $10.2307 / 3237203$

Buurman P, van Lagen B, Velthorst EJ (1996) Manual for soil and water analysis. Publishers Leiden, Backhuys, p 314

Catovsky S, Bazzaz FA (2002) Feedbacks between canopy composition and seedling regeneration in mixed conifer broad-leaved forests. Oikos 98:403-420. doi:10.1034/j.1600-0706.2002.980305.x

Cline E, Vinyard B, Edmonds R (2007) Spatial effects of retention trees on mycorrhizas and biomass of Douglas-fir seedlings. Can J For Res 37:430-438. doi:10.1139/X06-229

De Andrés EG, Camarero JJ, Martínez I, Coll L (2014) Uncoupled spatiotemporal patterns of seed dispersal and regeneration in Pyrenean silver fir populations. For Ecol Manag 319:18-28. doi:10.1016/j.foreco.2014.01.050

Diaci J (2002) Regeneration dynamics in a Norway spruce plantation on a silver fir beech forest site in the Slovenian Alps. For Ecol Manag 161:27-38. doi:10.1016/S0378-1127(01)00492-3

Efron B, Tibshirani RJ (1993) An introduction to the bootstrap. Chapmann\&Hall/CRC, NewYork

Frankland JC (1998) Fungal succession - unravelling the unpredictable. Mycol Res 102:1-15. doi:10.1017/S0953756297005364

Grassi G, Bagnaresi U (2001) Foliar morphological and physiological plasticity in Picea abies and Abies alba saplings along a natural light gradient. Tree Physiol 21:959-967. doi:10.1093/treephys/21.12-13.959

Grebenc T, Christensen M, Vilhar U, Čater M, Martín MP, Simončič P, Kraigher H (2009) Response of ectomycorrhizal community structure to gap opening in natural and managed temperate beech-dominated forests. Can J For Res 39:1375-1386. doi:10.1139/X09-072

Hofmeister Š, Svoboda M, Souček J, Vacek S (2008) Spatial pattern of Norway spruce and silver fir natural regeneration in uneven-aged mixed forests of northeastern Bohemia. J For Sci 54:92-101

Hunziker U, Brang P (2005) Microsite patterns of conifer seedling establishment and growth in a mixed stand in the southern Alps. For Ecol Manag 210:67-79. doi:10.1016/j.foreco.2005.02.019

Jackson ML (1958) Soil chemical analysis. Prentice Hall, Englewood Cliffs, p 498

Jaworski A (1973) Odnowienie naturalne jodły (Abies alba Mill.) w wybranych zbiorowiskach leśnych Parków Narodowych: Tatrzańskiego, Babiogórskiego i Pienińskiego. Acta Agr et Silv ser Silv 13:21-87

Jonard M, Andre F, Ponette Q (2006) Modeling leaf dispersal in mixed hardwood forests using a ballistic approach. Ecology 87:23062318. doi:10.1890/0012-9658(2006)87[2306:MLDIMH]2.0.CO;2

Kotanen PM (2007) Effects of fungal seed pathogens under conspecific and heterospecific trees in a temperate forest. Can J Bot 85:918-925. doi:10.1139/B07-088

Liski J (1995) Variation in soil organic carbon and thickness of soil horizons within a boreal forest stand: effect of trees and implications for sampling. Silva Fenn 29:255-266. doi:10.14214/sf.a9212

Marczyk M (2012) Uwalnianie i dyspersja nasion Abies alba Mill. we wnętrzu drzewostanu - estymacja parametrów i walidacja modeli. Praca magisterska. Agricultural University in Krakow, Krakow, p 41

Mori AS, Komiyama A (2008) Differential survival among lifestages contributes to co-dominance of Abies mariesii and Abies veitchii in a subalpine old-growth forest. J Veg Sci 19: 239-244. doi: $10.3170 / 2008-8-18364$
Nagel TA, Svoboda M, Rugani T, Diaci J (2010) Gap regeneration and replacement patterns in an old-growth Fagus-Abies forest of Bosnia-Herzegovina. Plant Ecol 208:307-318. doi:10.1007/s11258-009-9707-z

Nopp-Mayr U, Kempter I, Muralt G, Gratzer G (2012) Seed survival on experimental dishes in a central European old-growth mixed-species forest: effects of predator guilds, tree masting and small mammal population dynamics. Oikos 121:337-346. doi:10.1111/j.1600-0706.2011.19099.x

Nuttle T, Haefner JW (2005) Seed dispersal in heterogeneous environments: bridging the gap between mechanistic dispersal and forest dynamics models. Am Nat 165:336-349. doi: $10.1086 / 428298$

Otto HJ (1994) Waldökologie. Verlag Eugen Ulmer, Stuttgart, p 391

Paluch J (2005a) The influence of the spatial pattern of trees on forest floor vegetation and silver fir (Abies alba Mill.) regeneration in uneven-aged aged forests. For Ecol Manag 205:283-298. doi:10.1016/j.foreco.2004.10.010

Paluch J (2005b) Spatial distribution of regeneration in WestCarpathian uneven-aged silver fir forests. Eur J For Res 124: 47-54. doi:10.1007/s10342-005-0054-x

Paluch J (2011) Ground seed density patterns under conditions of strongly overlapping seed shadows in Abies alba Mill. stands. Eur J For Res 130:1009-1022. doi:10.1007/s10342-011-0486-4

Paluch J, Gruba P (2011) Inter-crown versus under-crown area: contribution of local configuration of trees to variation in topsoil morphology, $\mathrm{pH}$ and moisture in Abies alba Mill. forests. Eur. J For Res 131: 857-870. doi:10.1007/s10342-011-0559-4

Paluch J, Gruba P (2012) Effect of local species composition on topsoil properties in mixed stands with silver fir (Abies alba Mill.). Forestry 85:413-426. doi:10.1093/forestry/cps040

Paluch JG, Jastrzęskik R (2013) Natural regeneration of shade-tolerant Abies alba Mill. in gradients of stand species compositions: limitation by seed availability or safe microsites? For Ecol Manag 307: 322-332. doi:10.1016/j.foreco.2013.06.035

Paluch J, Stępniewska H (2012) Effect of microsites on the survival, density, and ectomycorrhizal status of shade-tolerant Abies alba regeneration attacked by fungal pathogens. Can J For Res 42:720 732. doi:10.1139/x2012-015

Paszyński J, Niedzwiedź T (1999) Klimat. In: Starkel L (ed) Geografia Polski. Środowisko przyrodnicze. PWN, Warszawa, pp. 288-343

Penne C, Ahrends B, Deurer M, Bottcher J (2010) The impact of the canopy structure on the spatial variability in forest floor carbon stocks. Geoderma 158:282-297. doi:10.1016/j.geoderma.2010.05.007

Rousset O, Lepart J (2000) Positive and negative interactions at different life stages of a colonizing species (Quercus humilis). J Ecol 88:401412. doi:10.1046/j.1365-2745.2000.00457.x

Roženbergar D, Mikac S, Anić I, Diaci J (2007) Gap regeneration patterns in relationship to light heterogeneity in two old-growth beechfir forest reserves in South East Europe. Forestry 80:431-443. doi:10.1093/forestry/cpm037

Saetre P (1999) Spatial patterns of ground vegetation, soil microbial biomass and activity in a mixed spruce-birch stand. Ecography 22:183192. doi:10.1111/j.1600-0587.1999.tb00467.x

Sagnard F, Pichot C, Dreyfus P, Jordano P, Fady B (2007) Modelling seed dispersal to predict seedling recruitment: recolonization dynamics in a plantation forest. Ecol Model 203:464-474. doi:10.1016/j.ecolmodel.2006.12.008

Schreiner M, Bauer EM, Kollman J (2000) Reducing predation of conifer seeds by clear-cutting Rubus fruticosus Agg. in two montane forest stands. For Ecol Manag 126:281-290. doi:10.1016/S0378-1127(99)00100-0

Schütt P (1991) Tannenarten Europas und Kleinasiens. Verlag Birkhäuser, Basel, p 136

Šimak M (1951) Untersuchungen über den natürlichen Baumartenwechsel in schweizerischen Plenterwäldern. 
Mitteilungen der Schweizerischen Anstalt für das Forstliche Versuchswesen 27:406-468

Snyder RE, Chesson P (2004) How the spatial scales of dispersal, competition, and environmental heterogeneity interact to affect co-existence. Am Nat 164:633-650. doi:10.1086/424969

Stadt KJ, Lieffers VJ (2000) MIXLIGHT: a flexible light transmission model for mixed-species forest stands. Agric For Meteor 102:235252. doi:10.1016/S0168-1923(00)00128-3

Staelens J, Nachtergale L, Luyssaert S, Lust N (2003) A model of windinfluenced leaf litterfall in a mixed hardwood forest. Can J For Res 33:201-209. doi:10.1139/x02-174

Suszka B (1983) Rozmnażanie generatywne. In: Białobok S (ed) Jodła pospolita Abies alba Mill. PWN, Warszawa, pp 175-265
Szwagrzyk J, Szewczyk J, Maciejewski Z (2012) Shade-tolerant tree species from temperate forests differ in their competitive abilities: a case study from Roztocze, south-eastern Poland. For Ecol Manag 282:28-35. doi:10.1016/j.foreco.2012.06.031

Wilson JB (2011) The twelve theories of co-existence in plant communities: the doubtful, the important and the unexplored. J Veg Sci 22: 184-195. doi:10.1111/j.1654-1103.2010.01226.x

Woods KD (1984) Patterns of tree replacement: canopy effects on understory pattern in hemlock-northern hardwood forests. Vegetatio 56: 87-107. doi:10.1007/BF00033051

Yamazaki M, Iwamoto S, Seiwa K (2009) Distance- and densitydependent seedling mortality caused by several diseases in eight tree species co-occurring in a temperate forest. Plant Ecol 201:181-196. doi:10.1007/s11258-008-9531-x 